\title{
Perspectives over the Brazilian iron-niobium production
}

\begin{abstract}
Brazil is the country with the largest niobium reserve in the world. However it is necessary that the country invest in technology to add value to products derived from niobium such as air turbines, automobiles, gas pipelines, tomographs used for magnetic resonance imaging, as well as optical lenses, high intensity lamps, electronic goods and even piercings in the aerospace, nuclear seeking the self-development of the country always in a sustainable way.
\end{abstract}

Keywords: exploitation, development, forecast, iron, niobium, production
Volume 2 Issue I - 2018

\author{
Diogo José Horst \\ Department of Production Engineering, Federal University of \\ Technology, Brazil
}
Correspondence: Diogo José Horst, Department of
Production Engineering, Federal University of Technology, Brazil,
Paraná, Zip Code 84016-210, Tel +55(42)3220-4800,

Email diogohorst@gmail.com

Received: January 3I, 2018 | Published: February 06, 2018

\section{Opinion}

Niobium is a chemical element, symbol $\mathrm{Nb}$, atomic number 41 (41 protons and 41 electrons) and atomic mass $92.9 \mathrm{u}$. It is a transition element belonging to the group 5 or $5 \mathrm{~B}$ of the periodic classification of the elements. The name derives from the Greek goddess Níobe, daughter of Dione and Tantalus-the latter, in turn gave name to another element of the family 5B, tantalum. It is used mainly in alloys of steel for the production of conductive tubes of fluids. Under normal conditions, it is solid. It was discovered in 1801 by the Englishman Charles Hatchett. ${ }^{1}$ It is used to bond in the manufacture of specialty steels and is one of the most resistant metals to both corrosion and external temperatures. It is also a superconducting metal and its melting point (melting) is at $2,468^{\circ} \mathrm{C}$, while its evaporation point is at $4744^{\circ} \mathrm{C}$. If added (in grams) proportionally to the ton of steel, it can give greater tenacity and lightness to the material. ${ }^{2}$ Nowadays, this mineral element is used in the manufacture of air turbines, automobiles, gas pipelines, tomographs used for magnetic resonance imaging, as well as optical lenses, high intensity lamps, electronic goods and even piercings in the aerospace, nuclear.

$98 \%$ of niobium reserves are in Brazil; in contrast, the Federal Government does not have a specific policy for the commercialization of niobium in Brazil. The country currently accounts for more than $90 \%$ of the volume of metal traded on the planet, followed by Canada and Australia. In the country, reserves are in the order of $842,460,000$ tons and the largest deposits are in the states of Minas Gerais (75\% of the total), Amazonas (21\%) and Goiás (3\%). According to the National Mining Plan 2030 report, ${ }^{3}$ Brazil currently exploits 55 mineral substances, accounting for more than $4 \%$ of global production, and is the world leader in niobium production alone. In the case of iron and manganese, for example, where the country also occupies a prominent position, the share of global production does not exceed $20 \%$. The total production in Brazil is fully utilized by Companhia Brasileira de Metalurgia e Mineração - CBMM (MG), Mineração Catalão de Goiás (GO) (Anglo American) and, to a lesser extent, Mineração Taboca (AM), which operate in a using the concentrate for the production of iron-niobium alloy, other alloys and niobium oxide. There is no commercialization of the crude or concentrated ore (pyrochlor) in the internal or external market. The niobium reserves in Brazil are located in the states of Minas Gerais, Amazonas and Goiás. In 2008, the price of the iron-niobium alloy reached an average price of US\$ $\$ 3$ thousand/t, reflecting the appreciation of international commodities. In 2006 , the average price was close to US $\$ 14,000 / t$.

Still according to the Ministry of Mines and Energy, ${ }^{3}$ in 2015 the production of niobium in the country was $83 \mathrm{kt}$ with direct participation of 880 jobs, already in 2022 is estimated that production reaches $113 \mathrm{kt}$ generating 1,199 job vacancies, and by 2030 production reaches $161 \mathrm{kt}$ and 1,708 direct jobs. Already the forecast of the investments in mineral transformation (US\$/t 6,390) during the period 2010-2015 was 141million dollars, 2016-2022 is 191million dollars, and for 2023-2030 is 637million dollars. The projections for the demand for niobium, in the form of concentrate, expressed in $\mathrm{Nb}_{2} \mathrm{O}_{5}$ contained, are in the order of $83 \mathrm{kt}$ for $2015,113 \mathrm{kt}$ in 2022 , and $161 \mathrm{kt}$ in 2030 . The concentrate feeds the miners' own integrated metallurgical plants, with no export of niobium concentrate. Already the forecast of investments in mineral research in 2010-2015 was 20, 3 million US\$, and in 2023-2030 will reach 32, 3million US\$. Some Brazilian universities, such as University of São Paulo (USP), State University of São Paulo (UNESP) and Federal University of Rio de Janeiro (UFRJ), investigate the characteristics of niobium in order to develop technologies in the superconducting sector, in the generation and transmission of electric energy, in the transportation system and in mining, being widely used in construction of mechanical, aeronautical, biomedical and nuclear equipment. ${ }^{4}$

Brazil exports the final product, iron-niobium alloy, super-resistant in the manufacture of rockets, space satellites, and turbines for jet engines, missiles and steel power plants. So it is necessary that the country invest in technology seeking its self development through the production of niobium. The main application of niobium is in the steel industry boosts exports of niobium. And the evolution of the price of niobium is also associated with the demand of the steel sector and the application of steel. For this reason, the decline in the market also accompanies the export trend. According to the Ministry of Development, Industry, Foreign Trade and Services, ${ }^{5}$ the volume of iron-niobium alloy exported increased $110 \%$ in 10years, from 33,688 tons in 2003 to 70,948 in 2012. The world demand for niobium has grown in recent years at a rate of $10 \%$ per year, mainly driven by Chinese purchases. The average price of the ton of ore shipped by Brazil in December was US \$ 50.40 - a $56 \%$ increase compared to December 2015 (US \$32.30) and 28.6\% before November 2016(39.2\% dollars). The volume exported in December 2017 of 35.1 million tons 
was also higher than in November 2017 (31.4 million tons), but fell below the 39.5 million tons shipped in December 2015-a record time. Vale S.A is the largest iron ore producer in the world and accounts for most shipments of the Brazilian commodity, while Companhia Siderúrgica Nacional (CSN) is the largest steel industry in Brazil and Latin America, and one of the largest in the world, responsible by the production of crude and rolled steel. Still according to the Ministry of Development, Industry, Foreign Trade and Services, ${ }^{5}$ Brazilian iron ore exports and its concentrates in 2016 reached a record volume of 373.962 million tons, an increase of 1.7percent over 2015. With niobium Brazil cannot repeat the same mistake of selling iron ore to other countries in order to process it and return it in the form of ingot or other finished products, thereby losing jobs, incomes, research \& development and technology transfer. Reinforcing that Brazil must invest in high technology seeking a partnership between universities, research centers and industries, selling finished products with high added value, always seeking to develop the national technology in sustainable ways.

\section{Acknowledgements}

None.

\section{Conflict of interest}

The authors declare that there is no conflict of interest.

\section{References}

1. Department of Materials Science \& Metallurgy / University of Cambridge (1801) Niobium and Iron-Niobium Production "Niobium was discovered first by Charles Hatchett in; Anders Gustaf Ekeberg discovered tantalum, UK.

2. Wong TM. Niobium: Properties, Production and Applications (Chemical Engineering Methods and Technology). Nova Science Publishers, USA; 2010. p. 443.

3. Ministry of Mines and Energy. National Mining Plan 2030 (PNM-2030). Brasília, MME, Brazil; 2010. p. 178.

4. Brazilians are advancing towards niobium superalloys. Information from the USP Agency, Brazil.

5. Ministry of Development, Industry, Foreign Trade and Services. Exports of iron ore, Brazil. 